Studia UBB \$耳igitalia, Volume 65 (LXV) 2020, December, Issue 2, 7-20

Published Online: 2021-01-25

DOI: 10.24193/subbdigitalia.2020.2.01

\title{
The Construction of a Database with the Pupils of the Greek Catholic High School in Beius and the Geographic Visualization of their Birthplace (1876/1877 School Year)
}

\author{
Alexandru-Augustin Haiduc ${ }^{1}$
}

\begin{abstract}
The article discusses the implementation of a database presenting the pupils that studied at the Greek Catholic High School in Beius in the $1876 / 1877$ school year and presents a series of geographic annotations made on a map of the Habsburg Empire, opened in QGIS, consisting in the birthplaces of the aforementioned pupils. The database and the geographic annotations presented here are already being developed to include further pupils that studied at the Greek Catholic High School in Beius subsequent to the 1876/1877 school year. Therefore, the database and the geographic annotations are a pilot version of a broader project meant to conclude into a monograph regarding the Greek Catholic High School in Beiuș in the $19^{\text {th }}$ century and first quarter of the $20^{\text {th }}$ century.
\end{abstract}

Keywords: database, Airtable, QGIS, Beiuș, high school, 1876/1877 school year

\section{Argument}

The historian Blaga Mihoc remarks, in one of his works, that the history of the Greek Catholic High School in Beiuș/Belényes is largely cleared, despite few and less exploited primary sources being left aside ${ }^{2}$. At first sight, it seems tempting to subscribe to Mr. Mihoc's assertion, but a thorough analysis brings up the fact that actually no solid historical monograph of the respective school has been published. As detailed below, the historical literature of the topic is either methodologically outdated or it deals with only minor aspects of the High School. Therefore, I believe a

\footnotetext{
${ }^{1} 2^{\text {nd }}$ year MA student, History; haiduc_alexandru1996@yahoo.ro.

2 Mihoc, Blaga. Biserică și societate în nord-versul României. Contribuții monografice (Church and Society in Northwestern Romania. Monographic Contributions), Editura Logos '94, 2003, p. 117.
} 
re-evaluation is not only legitimate, but also highly needed and the present paper is a step forward towards this aim.

\section{The Historiography of the Subject}

The historiography of the Greek Catholic High School in Beiuș largely overlaps the historiography of the Greek Catholic Eparchy of Oradea/Nagyvárad/Großwardein. However, if historical research about the eparchy was prohibited during the communist regime, literature on the high school has been published, within the framework of the larger topic of the Romanian national movement.

The historiography of the Greek Catholic High School in Beiuș published prior to 1948 is mostly laudatory and lacking in critical perspective. This owes substantially to the social background of those who wrote about education within the Greek Catholic Eparchy of Oradea, mostly clerics or teachers. The two monographs, written by Traian Farcaș ${ }^{3}$ and Constantin $\mathrm{Pavel}^{4}$, are illustrative for the aforementioned historiographical context. The first one was published following the mandatory stipulations of the Hungarian legislation, while the second one was published on the centenary of the Greek Catholic High School in Beiuș. Further information is also provided by the works of Petru Tămăian ${ }^{5}$ and Petru Papp ${ }^{6}$, but also by the monographs of the Greek Catholic Bishopric of Oradea ${ }^{7}$ and its bishops (e.g. Mihail Pavel) ${ }^{8}$.

After 1948, the research on the Greek Catholic High School in Beiuș became scarcer, yet more methodical, as those preoccupied with the subject were professional historians from institutions such as The 'Criș Country' Museum?', the Bihor County Service

\footnotetext{
${ }^{3}$ Farkas, Traian. Istoria Gimnaziului gr. cat. de Beiuș (1828-1895) (The History of the Greek Catholic High School in Beiuș. 1828-1895), Tipografia Aurora, 1896.

${ }^{4}$ Pavel, Constantin. Școalele din Beiuș. 1828-1928. Cu o privire asupra trecutului Românilor din Bihor (The Schools of Beiuș. 1828-1928. A Look on the History of the Romanians from Bihor County), Tiparul Tipografiei Doina, 1928.

5 Tămăian, Petru. Istoria seminarului și a educației clerului diecezei române unite de Oradea (The History of the Seminary and of the Education in the Greek Catholic Diocese of Oradea), Tipografia și litografia românească, 1930.

${ }^{6}$ Papp, Petru. Din trecutul Beiușului, pagini de glorie și de jertfe (From Beiuș' History, Pages of Glory and Sacrifices), Tiparul Tipografiei Doina, 1928.

${ }^{7}$ Radu, lacob. Istoria diecezei române unite a Orăzii Mari, 1777-1927. Scrisă cu prilejul aniversării de 150 de ani dela înființarea aceleia (The History of the Greek Catholic Diocese of Oradea, 1777-1927. Written with the Occasion of the Celebration of 150 Years since Its Founding), Chiriașii tipografiei românești, 1932. ${ }^{8}$ Georgescu, Ioan. Episcopul Mihail Pavel: viața și faptele lui (1827-1902). La o sută de ani dela nașterea și la douăzeci și cinci dela moartea lui (Bishop Mihail Pavel: Life and Deeds (1827-1902). On the Occasion of 100 Years since His Birthdate and 25 Years since His Death), Tipografia și Librăria Românească Societate Anonimă, 1927; Bojor, Victor. Episcopii Diecesei Gr. Cat. de Gherla acum ClujGherla (1856-1939): biografii precedate de o introducere istorică documentară, cu mai multe ilustrații în text (The Bishops of the Greek Catholic Diocese of Gherla, now Cluj-Gherla (1856-1939): Biographies Preceded by a Historically Documented Introduction, with Multiple Illustrations), 2nd ed., Editura Viața Creștină, 2000.

${ }^{9}$ Dudaș, Florian. "În legătură cu cel mai vechi anuar al gimnaziului din Beiuș" (About the Oldest Yearbook of the Beiuș High School). Crisia, no. 34, 2004, pp. 171-179; Faur, Viorel. "Din istoricul preocupărilor etnografice și folcloristice referitoare la așezările din Depresiunea Beiușului (1816-1918)" (About the History of the Ethnographic and Folkloristic preoccupations regarding the Beius Depression. 1816-1918). Biharea, no. 2, 1974, pp. 107-118; Faur, Viorel. "Istoricul bibliotecii Societății literare „Samuil Vulcan” din Beius (18621918)" (The History of the Library of the "Samuil Vulcan" Literary Society from Beiuș. 1862-1918). Biblioteca și școala, 1976, pp. 157-171; Faur, Viorel. "Societatea literară „Samuil Vulcan” din Beiuș” (The "Samuil Vulcan” Literary Society from Beiuș). Crisia, no. 4, 1974, pp. 246-298
} 
of the National Archives $^{10}$ or the University of Oradea ${ }^{11}$, but also from neighboring counties $^{12}$. After 1989, the history of the Greek Catholic High School in Beiuș gains a place in the revived historical writing on the Greek Catholic Eparchy of Oradea ${ }^{13}$.

\section{Sources and methodological aspects}

Despite the rich and apparently thorough literature on the topic, the research supporting this paper is rooted mainly in unpublished sources preserved in the High School's archival fund at the Bihor County Service of the National Archives, mostly the yearly evidence of the pupils. Further information can be found in the fund of the Greek Catholic Bishopric, hosted by the same archival service. The yearly evidence registers the name, surname, confession, birthdate and birthplace, conduct, grades and other information about the pupils, such as the name, surname and social status of the

\footnotetext{
${ }^{10}$ Călușer, ludita. "Un moment semnificativ din relațiile stabilite între școlile românești din Blaj, Beiuș și Năsăud în lupta pentru învățământul românesc" (An Important Moment in the Relations between the Romanian High Schools from Blaj, Beiuș, and Năsăud in the fight for Romanian education). Crisia, no. 8, 1978, pp. 417-431; Călușer, ludita; Mălinaș, Constantin. "Contribuţii la cunoaşterea vieţii şi activităţii cărturarului bihorean loan Munteanu (1806-1860)" (Contributions regarding the life and the activity of Ioan Munteanu, scholar from Bihor. 1806-1860). Crisia, no. 11, 1981, pp. 141-160; Milian, Radu. "Școala ortodoxă și greco-catolică în Bihor în a doua jumătate a secolului XIX" (Orthodox and Greek Catholic Schools in Bihor in the Second Half of the 19th Century). Crisia, no. 30, 2000, pp. 229-255.

${ }^{11}$ Crăciun, Corneliu. Sub destinul care arde. Ioan Bușiția, Editura Logos '94, 2003; Hădăreanu, Gavril. Torțe arzânde în țara Beiusului (Burning Torches in the Beiuș Country), Editura Buna Vestire, 1995; Indrieș, Magdalena. Studiile clasice la gimnaziul din Beiuș (Classical Studies at the Beiuș High School). in Buzalic, Alexandru; Popescu, Ionuț Mihai, 230 de ani de la înființarea Eparhiei Române Unite de Oradea Mare, Presa Universitară Clujeană, 2008, pp. 483-494; Mălinaș, Constantin. "Anuarul Liceului de la Beiuș la anul 1845" (The 1845 Yearbook of the Beiuș High School). Crișana plus, 16th of March 2003, p. 6.

${ }^{12}$ Andea, Susana; Andea, Avram. "Ratio educationis" și înfiiințarea districtului școlar Oradea" ("Ratio educations" and the Foundation of the Educational District of Oradea). Crisia, no. 23, 1993, pp. 175185; Neagu, Răzvan Mihai. "Studenți din comitatul Bihor la Facultatea de Teologie a Universității din Cernăuti (1875-1918)" (Romanian Students from the County of Bihor at the Faculty of Theology from the University of Cernăuți. 1875-1918). Crisia, no. 47, 2017, pp. 127-140; Pop, Aurel. "Theodor Köváry (Chioreanu), un vestit profesor la Beiuș născut la Portița". (Theodor Köváry (Chioreanu), a Famous Teacher of Beiuș born in Portița) Acta Musei Porolissensis, no. 34, 2012, pp. 173-176.

${ }^{13}$ Căluser, ludita. Episcopia greco-catolică de Oradea. Contribuții monografice (The Greek Catholic Bishopric of Oradea. Monographic Contributions), Editura Logos '94, 2000; Călușer, ludita. Liceul român unit de fete din Beiuș. 1896-1948. Monografie istorică (The Girls' Greek Catholic High School in Beiuș. 1896-1948. Historical Monograph), Editura Logos '94, 2011; Mălinaș, Constantin. Călușer, ludita. Biblioteca Gimnaziului Greco-Catolic de Băieți din Beiuș: 1828-1918 (The Library of the Greek Catholic High School in Beiuș: 1828-1918), Editura Logos '94, 2006; Călușer, ludita. "Instrucția preoților grecocatolici din episcopia de Oradea în secolul al XIX-lea" (The preparation of the Greek Catholic Priests from the Bishopric of Oradea in the 19th Century). Crisia, no. 26-27, 1996-1997, pp. 97-117; Călușer, ludita. "Repere privind asociațiile și reuniunile cadrelor didactice greco-catolice din comitatul Bihor (1875-1923)" (Landmarks Regarding the Associations and Reunions of the Greek Catholic Teachers from the Bihor County. 1875-1923). Crisia, no. 23, 1993, pp. 215-222; Mihoc, Biserică și societate; Mihoc, Blaga. În sprijinul cetății. Studii, articole și o addenda (În sprijinul cetății. Studies, articles, and an Addendum), Editura Primus, 2019; Mihoc, Blaga. "Salarii, burse și împrumuturi. Contributii la istoria Eparhiei grecocatolice de Oradea" (Salaries, scholarships, and loans. Contributions to the History of the Greek Catholic Bishopric of Oradea). Crisia, no. 43, 2013, pp. 131-150; Sana, Silviu-lulian. În slujba neamului: aspecte din istoria Episcopiei Greco-Catolice de Oradea (În slujba neamului: Aspects of the History of the Greek Catholic Bishopric of Oradea), Editura Primus, 2017; Sana, Silviu-lulian. „... pentru sufletele credincioșilor săi...”. Structuri bisericești și școlare în Eparhia Greco-Catolică de Oradea-Mare (1850-1900) (,... pentru sufletele credincioșilor săi...". Church and Educational Structures in the Greek Catholic Eparchy of Oradea. 1850-1900), Editura Universității din Oradea, 2011.
} 
father, mother and/or guardian. The documents are written in Hungarian, in a standardized, easily understandable, form.

The information they provide was complemented by data from the school's yearbooks. The latter had been published regularly beginning with the 1876/1877 school year, and were edited by the head teachers of the high school starting with Petru Mihuțiu ${ }^{14}$. Corroborating the above-mentioned sources, and by means of digital tools, I aim at constructing a database with the high school's population in the mediumand long-term, in order to provide statistical series suitable for analyses.

Given that the main actors of the educational process are the students and the teachers, and taking into account the level of biographical information provided by the sources, my main approach will be prosopographical. Thus, the general goal of my research is to illustrate the evolution of the high school in the medium- and long-term, during the second half of the $19^{\text {th }}$ century and the first quarter of the $20^{\text {th }}$ century, in terms of social structure of its population. To this end I have turned towards quantitative methods and digital tools, in particular historical data structuring, database construction and digital geographic annotations.

Why 1876/77? Prior to 1876, the high school's yearbooks have been published irregularly and the information they provide is lacunar and hard to associate with the data from the yearly evidence of the pupils ${ }^{15}$. While future research will most certainly cover earlier decades too, at this point I chose to focus on the first school year fully covered by both categories of sources.

\section{The presentation of the database and of the geographic annotations}

So far, the optics of my analysis moved from general to specific, from the history of the Greek Catholic High School in Beiuș to the present research. Hereinafter, I will present the subject of my research from specific to general, from the case-study of a randomly selected student to the database and the geographic annotations.

\subsection{The construction of the database}

The pupil I will refer to is Bálta Nicolau ${ }^{16}$ and, as mentioned above, was selected arbitrarily. The database was created in Airtable ${ }^{17}$ and consists of a main table and other secondary tables linked to it. In the main table, each student was assigned an ID, based on the order recorded in the archival file, usually alphabetically for each grade (e.g. Bálta Nicolau was assigned ID no. 3). Further, I used different columns for the surname; Hungarian name of the pupil, as in the yearly evidence; Romanian name of the pupil, as in the yearbook (i.e. Bálta, Miklós, Nicolau). I also created three columns with predetermined options, one for the grade of the students, one for the confession of the

\footnotetext{
${ }^{14}$ Mihuțiu, Petru (ed.), Reportu despre Gimnasiulu sup. gr. cat. de Beiusiu pentru anulu scol 1876-1877 (Report Regarding the Greek Catholic High School in Beiuș in the 1876/1877 School Year), Tipariulu lui Ludovicu Hollósy, 1877.

${ }^{15}$ Dudaș, În legătură cu cel mai vechi anuar; Mălinaș, Anuarul.

${ }^{16}$ See the appendices.

${ }_{17}$ The database is available at the following link: https://airtable.com/shri1nSNjci1BgOwz.
} 
students, using the terminology from the yearbook (greco-catolică, greco-orientală, romano-catolică, helvetică, augustană, israelită), and a column with other information, such as if the student was given a scholarship or not, if the student was repeating the school year or not and so forth. In Bálta Nicolau's case, his grade was 1, the confession greco-orientală, i.e. Orthodox, and there were no mentions added. In some cases, mainly private students, the yearly evidence only offers information regarding the name and surname of the pupils and, occasionally, also the confession.

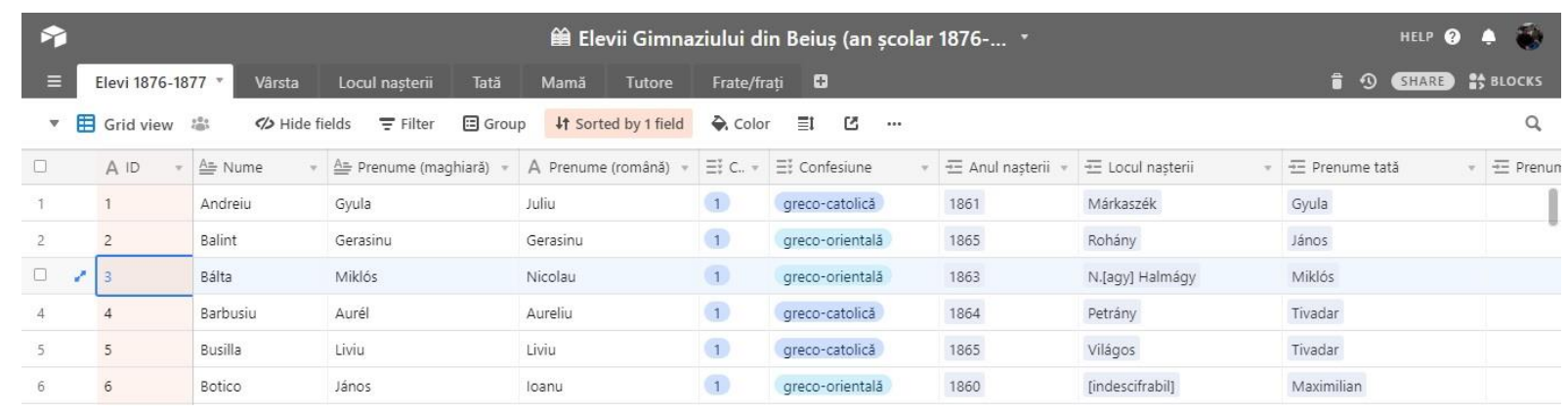

Fig. 1. Screenshot with the main table of the database

(https://airtable.com/shri1nSNjci1BgOwz, accessed 30 July 2020)

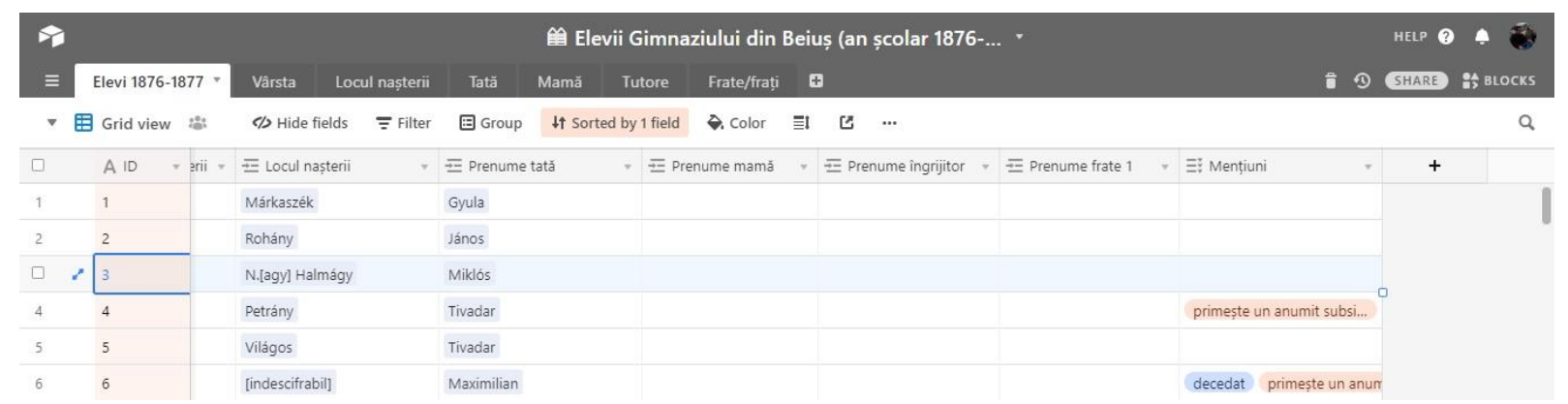

Fig. 2. Screenshot with the continuation of the main table of the database (https://airtable.com/shri1nSNjci1BgOwz, accessed 30 July 2020)

As for the secondary tables, one table illustrates the birthdate of the students. Each column, where the information was available, presents the year of birth, the month of birth (predefined selection) and the birthday. In Bálta Nicolau's case only the information regarding the birth year is available: 1863.

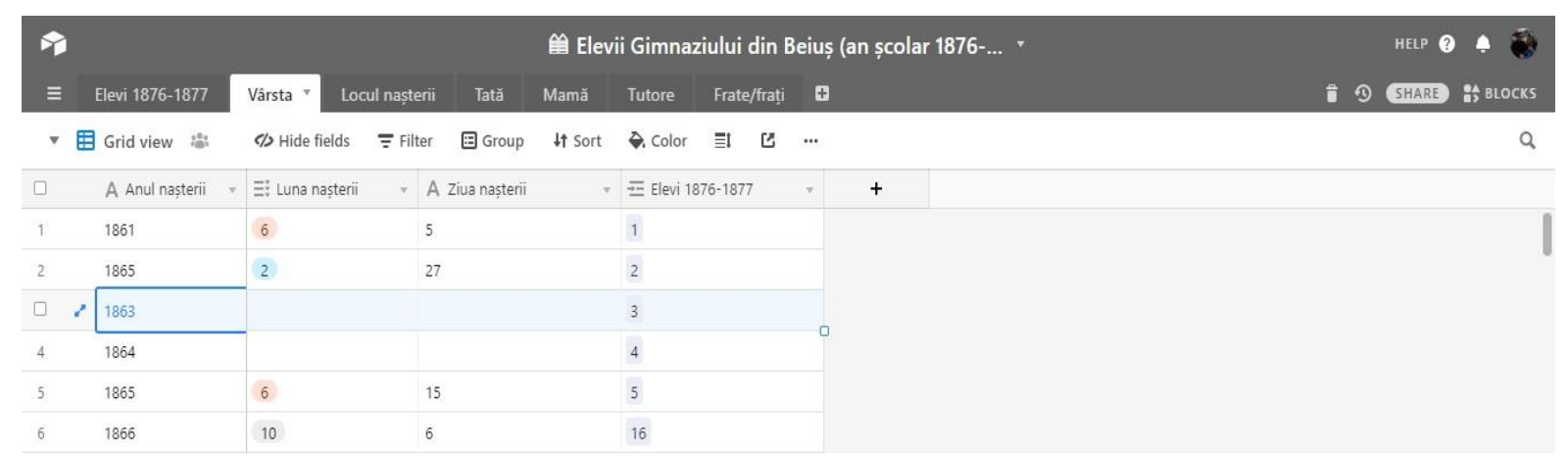

Fig. 3. Screenshot with the table presenting the birthdates of the pupils (https://airtable.com/shri1nSNjci1BgOwZ, accessed 30 July 2020) 
Another secondary table presents the birthplace of the students: the name of their birthplace in Hungarian, as in the yearly evidence, the present-day name of their birthplace, the county and the country or province of the Habsburg Empire. In Bálta Nicolau's case it is Nagy Halmágy, Hălmagiu, Zarand, Ungaria. Of historical interest is the fact that even in the cases of students born prior to the incorporation of Transylvania to Hungary (1867), some teachers make distinction between Transylvania and Hungary, while others do not.

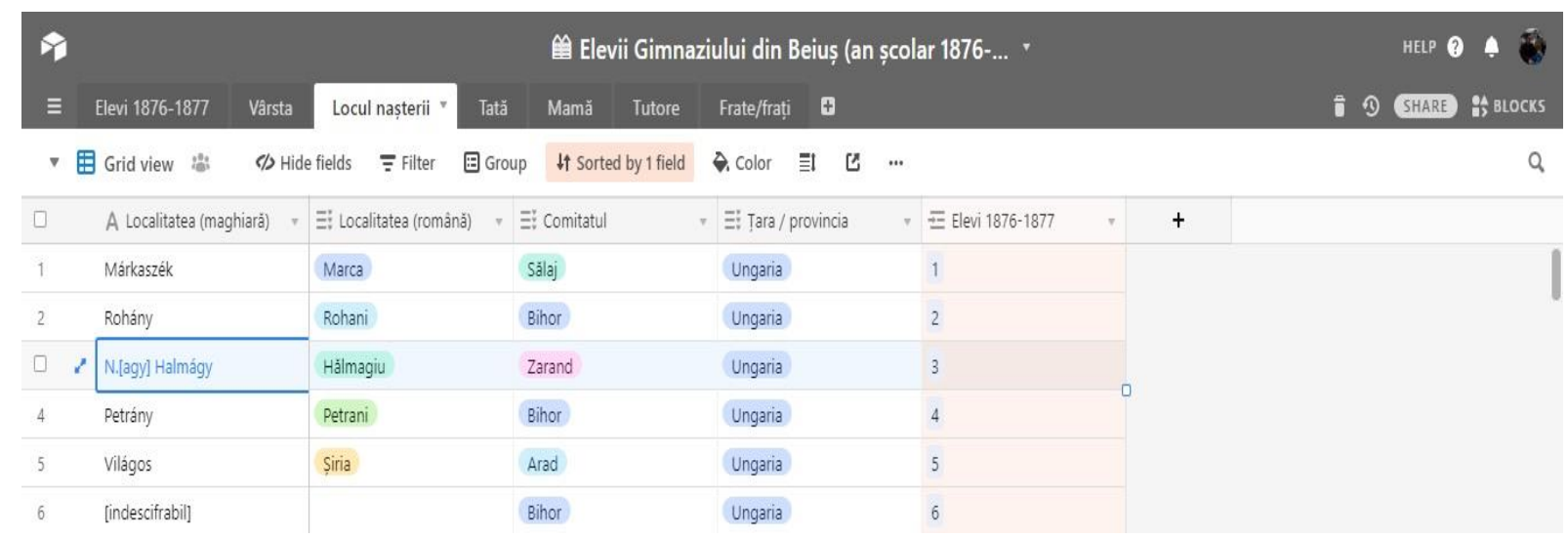

Fig. 4. Screenshot with the table concerning the birthplaces of the pupils (https://airtable.com/shri1nSNjci1BgOwZ, accessed 30 July 2020)

The tables Tată (Father), Mamă (Mother) and Tutore (Guardian) have a similar structure and consist of columns presenting the name, surname, social status and mentions regarding the social status. When the yearly evidence indicated an occupation, I introduced codes from the HISCO/HISCLASS ${ }^{18}$ classification systems of historical occupations: HISCO code, status code, relation code, product code, and HISCLASS code. For Bálta Nicolau, the name of the father was Miklós and his social status was that of farmer - țăran (földmivelö). Other frequent occupations are those of teacher (tanító), priest (lelkész), notary (jegyző or other forms), retailer (kereskedó), craftsperson (kézmüves). The HISCO code for țăran (földmivelö) is 61110 and the assigned HISCLASS code is 12. The HISCO/HISCLASS codes were added based on the sparse information offered by the yearly evidence and further information could determine the modification of the codes assigned. In Bálta Nicolau's case, I could not assign codes for status, relation and product. Usually, the column Mențiuni (Mentions) shows the place where the father, mother or guardian lived, and when they were well known persons, I added links to information from different online sources. Generally, the name and social status of the mother are mentioned in the yearly evidence only

\footnotetext{
${ }^{18}$ Historical International Standard Classification of Occupations (HISCO) is a system of classification of the historical occupations, based on ISCO-68, developed in the late 1990s. Complementary to the ten major groups associated with the occupations, HISCO uses codes for status, relation and product. Based on HISCO, International Social Class Scheme (HISCLASS) was developed, a scheme meant to place the individual in a historical social hierarchy made of 12 major groups. For further information, see: van Leeuwen, Marco H.D.; Maas, Ineke; Miles, Andrew. HISCO. Historical International Standard Classification of Occupations, Leuven University Press, 2002; van Leeuwen, Marco H.D.; Maas, Ineke. HISCLASS. A Historical International Social Class Scheme, Leuven University Press, 2011.
} 
when the father is deceased. Therefore, the status of the father was noted as deceased and that of the mother as widow - văduvă (özvegy, ozv.). Even though I encountered some cases of orphan pupils, the name and surname of guardian is not known in all cases and other pupils not mentioned as orphans have guardians.

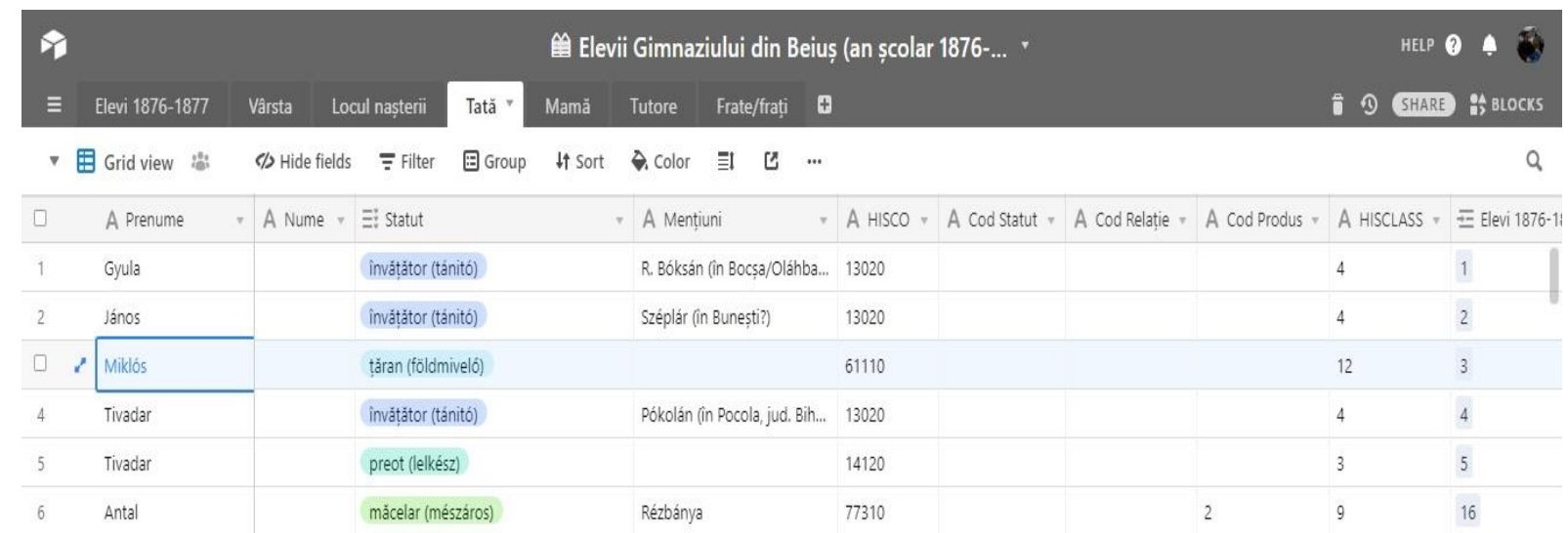

Fig. 5. Screenshot with the table Tată (Father)

(https://airtable.com/shrilnSNjci1BgOwz, accessed 30 July 2020)

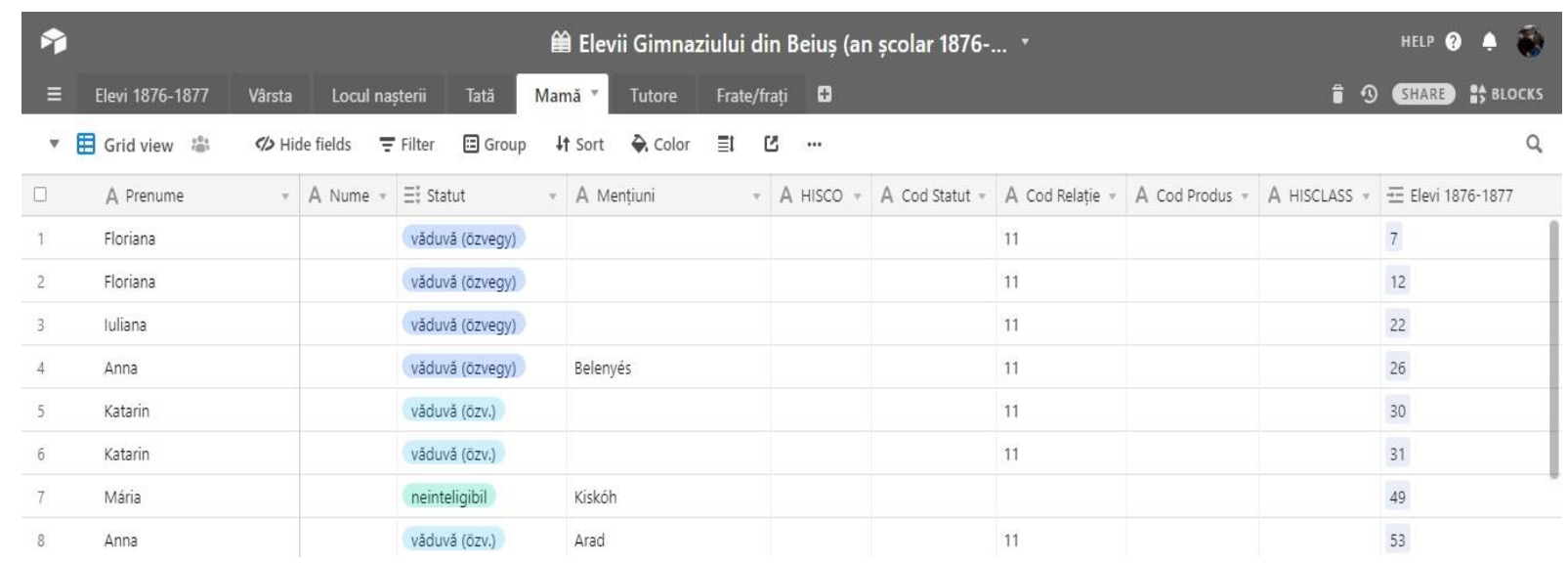

Fig. 6. Screenshot with the table Mamă (Mother)

(https://airtable.com/shrilnSNjci1BgOwz, accessed 30 July 2020)

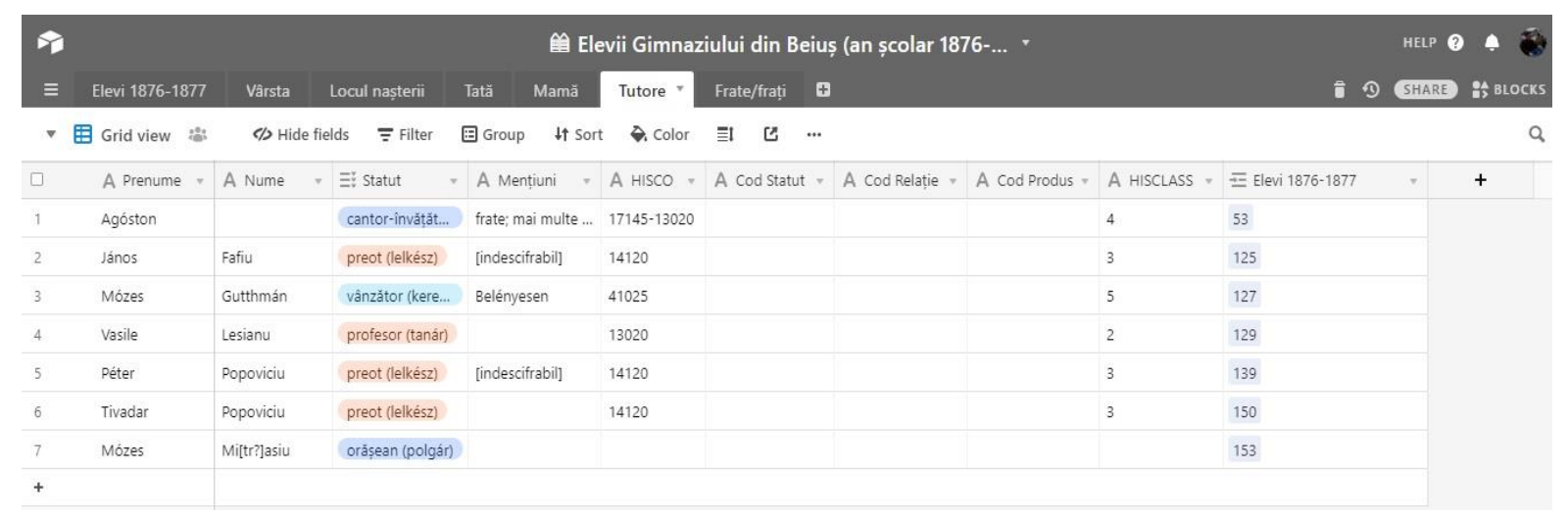

Fig. 7. Screenshot with the table Tutore (Guardian)

(https://airtable.com/shri1nSNjci1BgOwz, accessed 30 July 2020) 
In the case of some students, certain clues indicated that they were brothers. For instance, in the case of a pair of students bearing the same surname, with the same name of the father, the same occupation of the father and the same birthplace (for example, priest of the same confession, from the same village), I concluded that they were brothers and added them to the secondary table Frate/frați (Brother/brothers).

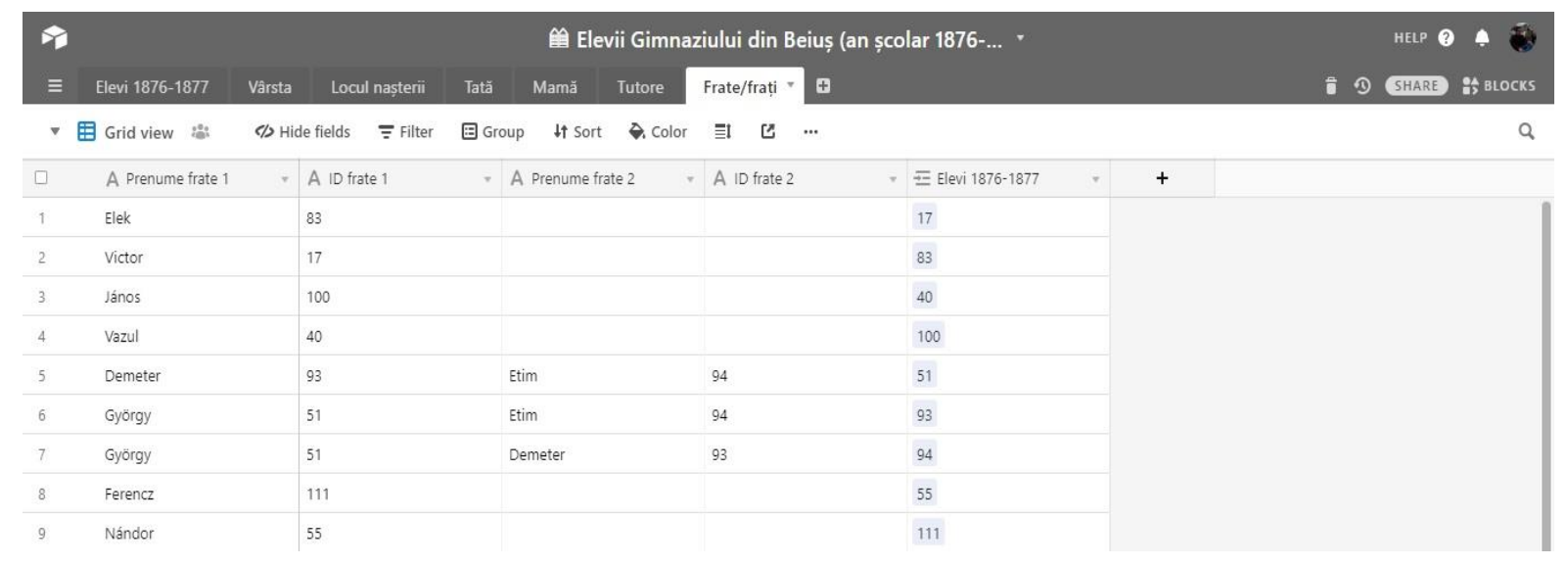

Fig. 8. Screenshot with the table Frate/frați (Brother/brothers)

(https://airtable.com/shri1nSNjci1BgOwZ, accessed 30 July 2020)

To summarize, a number of 203 students from the eight classes of education of the 1876/1877 school year were recorded. The subsequent school years are already being added to a different database that continues the database presented here $^{19}$. The Clasă (Class) column was modified into An și clasă (School year and class), and the classes were noted as follows: 1876/1877_1, 1876/1877_2, 1876/1877_3, and so on. HISCAM ${ }^{20}$ codes were also added to the extended database.

Airtable also offers a personal record for each pupil introduced in the database. The personal record presents the aforementioned information for each student.

\footnotetext{
${ }^{19}$ The database can be accessed at the following link: https://airtable.com/shrw3ycmoXbQ2gBYC.

${ }^{20}$ Lambert, Paul S. et alii. "The Construction of HISCAM: A Stratification Scale Based on Social Interactions for Historical Comparative Research." Historical Methods. A Journal of Quantitative and Interdisciplinary History, 46, no. 2, 2013, pp. 77-89.
} 


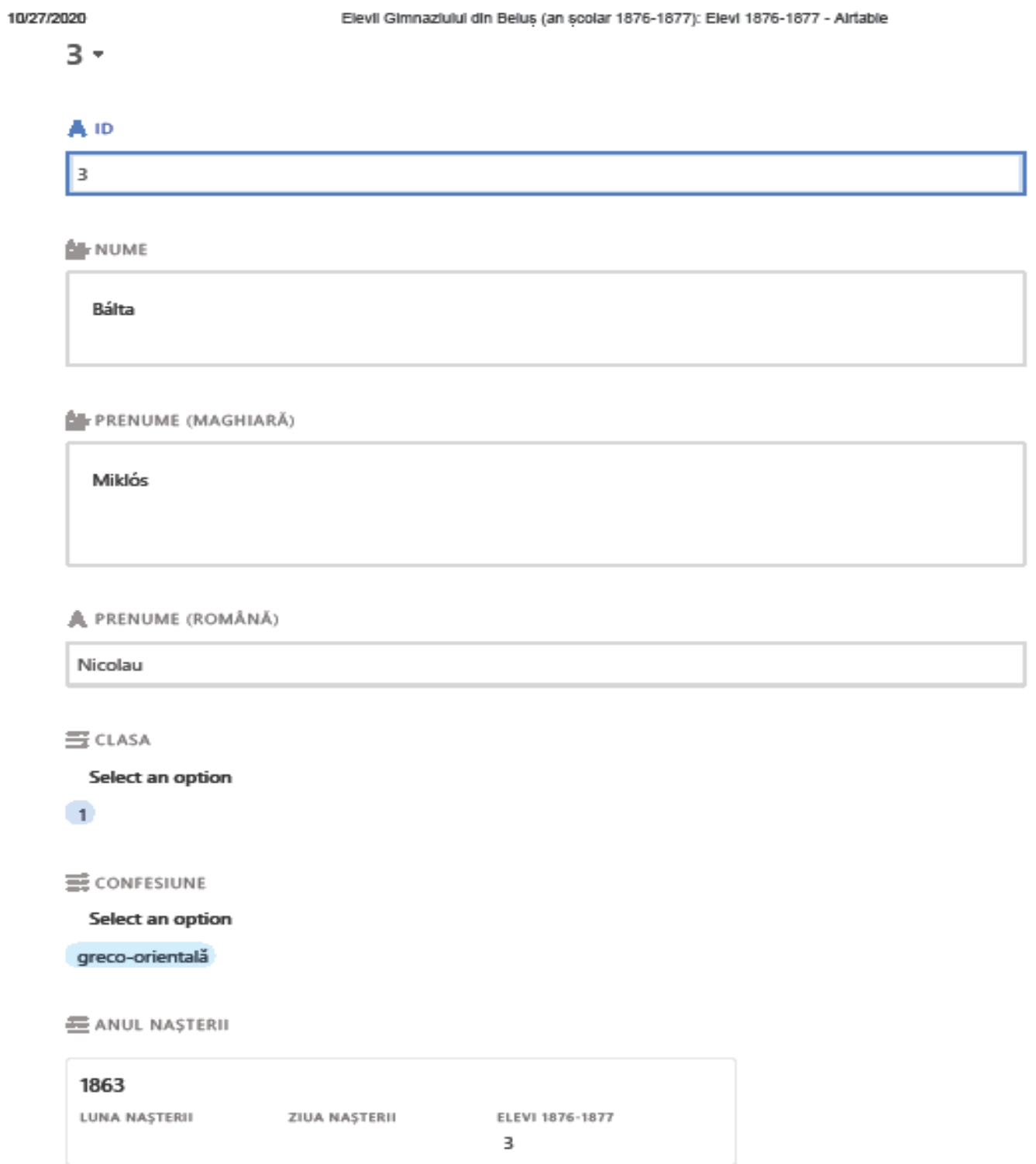

* Link to a record from Data nașterii

Fig. 9. Screenshot with the personal details of Bálta Nicolau (source:

https://airtable.com/shri1nSNjci1BgOwz, accessed 30 July 2020)

\subsection{The geographic annotations}

The geographic annotations were added using QGIS on an 1856 map of the Habsburg Empire, realized by Joseph von Scheda ${ }^{21}$. Although the map is apparently

21 The map is available at the following link: https://www.davidrumsey.com/luna/servlet/detail/ RUMSEY 8 1 201922 3000980:Composite-20-sheets--Karte-Des- 
bygone compared to the school year $1876 / 1877$, it is actually useful to recognizing the birthplace of the pupils, because their birthdate is more relevant to the date the map was published on than to that of the starting point of the school year.

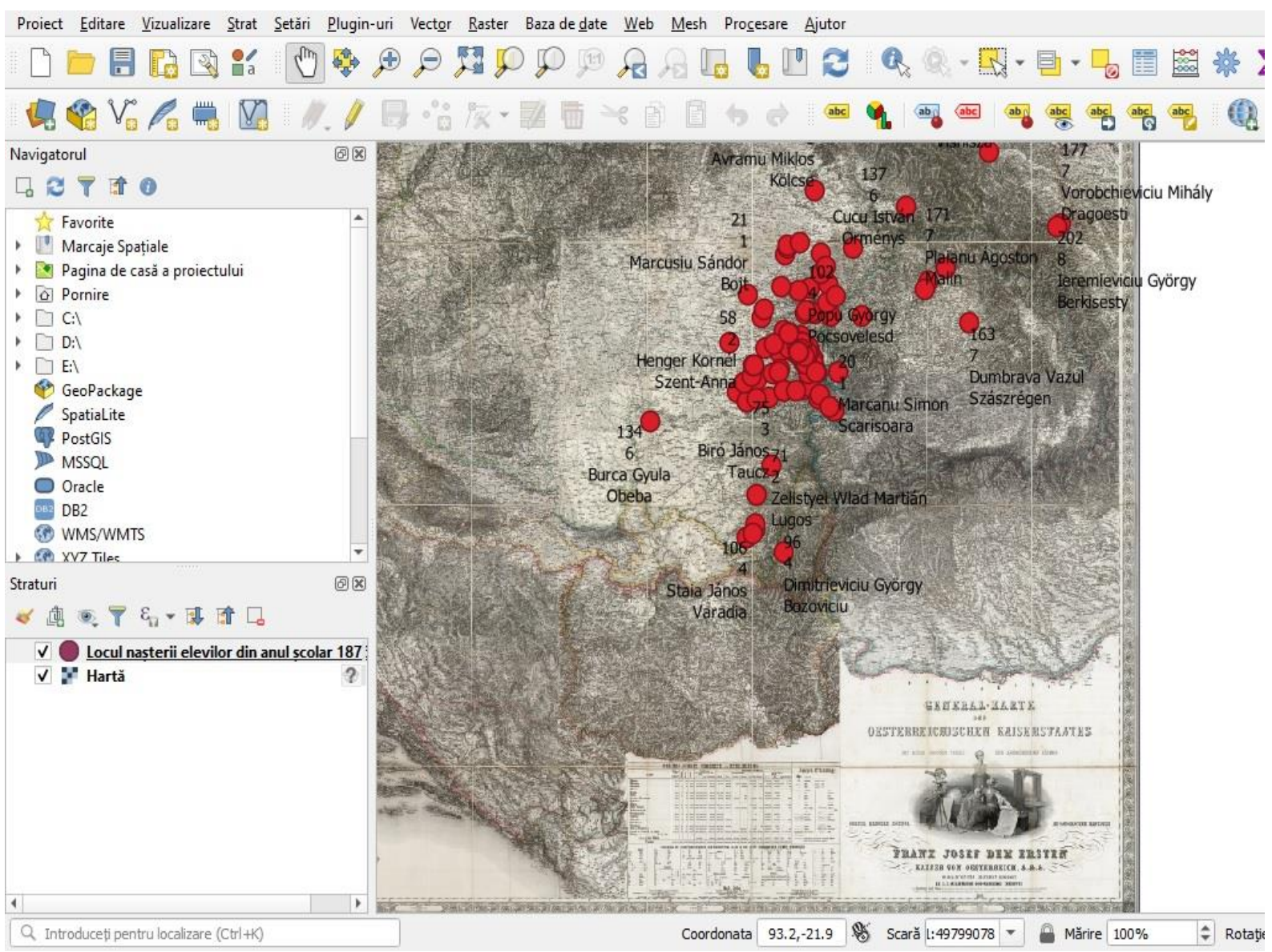

Fig. 10. Screenshot with a part of the map opened with QGIS

The aforementioned map was introduced as a layer in QGIS and the birthplaces of the students were marked as points on the map. Information regarding the ID from the database presented above, the grade, the surname and name in Hungarian, the county and the name of their birthplace, both in Hungarian and in their present-day Romanian counterpart, was attached to each point. Therefore, our sample student was noted as follows: ID 3, first grade, surname Bálta, name Miklós, county Zarand, birthplace Nagy Halmágy or Hălmagiu. 


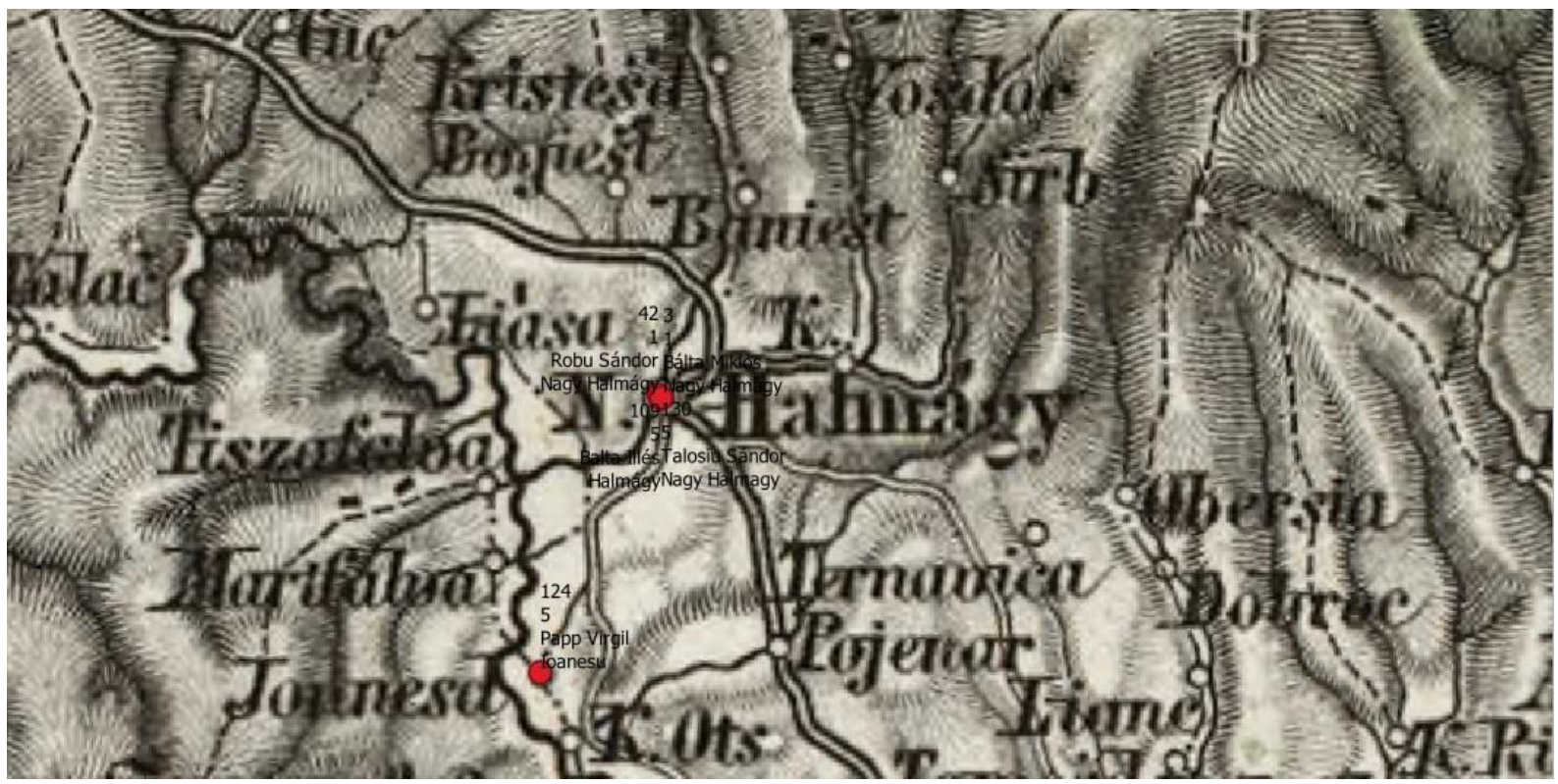

Fig. 11. Screenshot with a part of the map opened with QGIS, where Nagy Halmágy or Hălmagiu can be seen

The ID, grade, surname and name, and the name of the birthplace of the students in Hungarian is also available on the map, next to the point, not only in the attribute table. To outline, I attributed the birthplace of 160 students from the total of 203 students recorded in the database, because in some cases the name of the birthplace was illegible or not mentioned. The geographic annotations are currently being extended to the following school years, and the information regarding the class of the students was eliminated from QGIS in the new set of annotations.

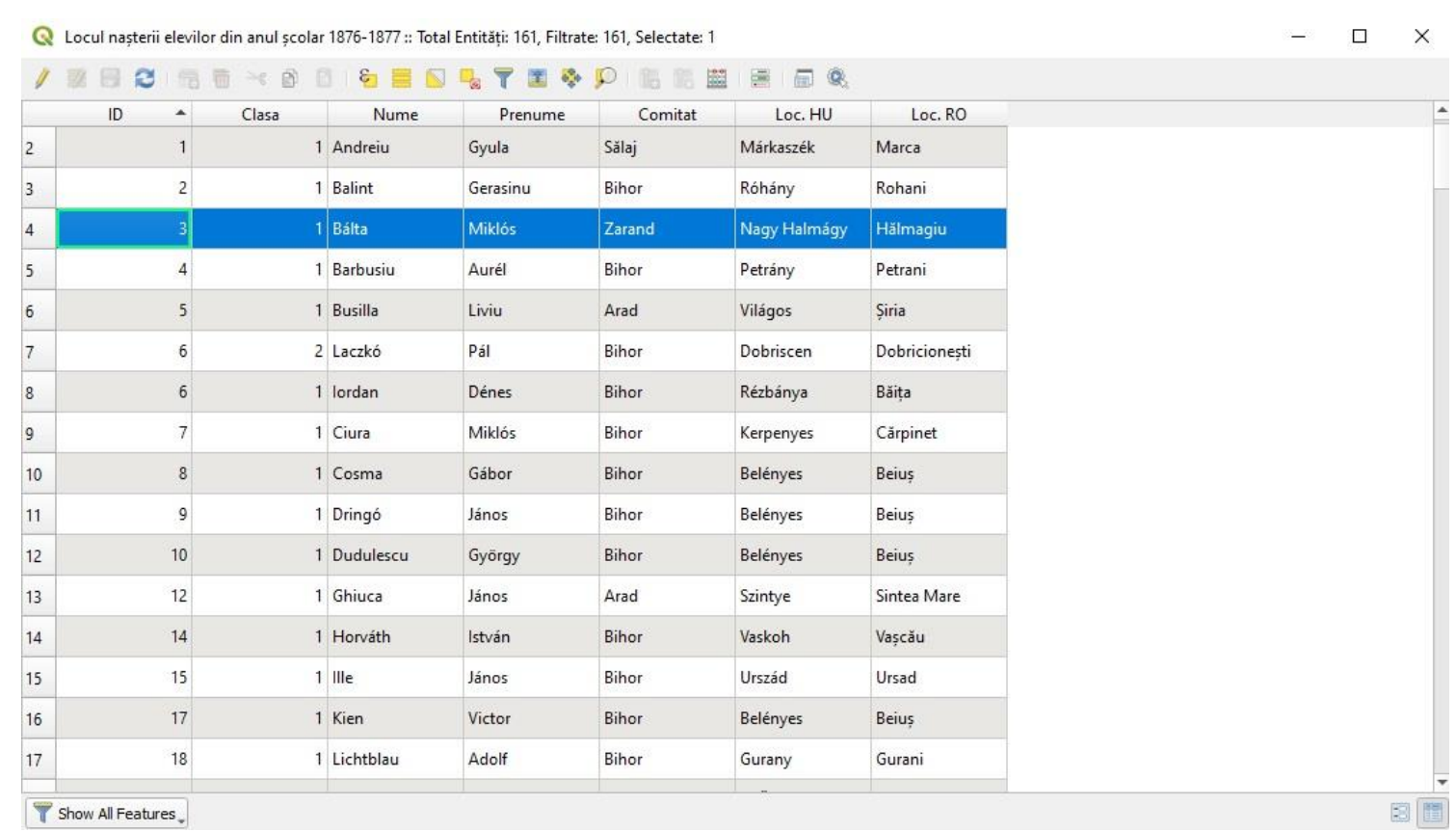

Fig. 12. Screenshot with the Attribute table presenting the points added to the layer in QGIS. 


\section{Conclusions}

To conclude, using the information provided by the yearly evidence and the yearbooks about the pupils that studied at the Greek Catholic High School in Beiuș in the 1876/1877 school year, I constructed a database in Airtable and a series of geographic annotations in QGIS. These instruments facilitate a more intricate overview of the pupil's personal information, and with it they support the elaboration of future research hypothesis and questions, the some of which are addressed below.

At the Greek Catholic High School in Beiuș, an educational institute supervized by the Greek Catholic Eparchy of Oradea, the majority of the students seems to be Orthodox. As a majority of the students seems to be born in the limits of the Eparchy, I believe that the High School served not only the interests of the Greek-Catholic population, but of the entire population that inhabited the territory of the Eparchy. Such a hypothesis could be tested by corroborating the information generated by the database and the geographic annotations with information provided by certain schematismus $^{22}$ of the Eparchy.

Corroborating data from a schematismus with the information facilitated by the database, it could be observed if the population of the Greek Catholic Eparchy of Oradea reached universal education. Precisely, it could be checked if the concept of fulfilment ${ }^{23}$, introduced by Raymond Grew, Patrick J. Harrigan and James Whitney to describe the moment when $85 \%$ of the children from a French department were scholarized and, thus, the department reached universal education, could be also applied in the case of the Greek Catholic Eparchy of Oradea. For instance, when I will have recorded, in the database, all the children from the county of Bihor, born in 1862, that studied at the Greek Catholic High School in Beiuș, I will be able to compare that number to the number of the entire population of Bihor, born in 1862. Furthermore, I could only consider the Romanian students, the vast majority of the students from Beius, and, thus, determine the scholarization of the Romanian population from Bihor, born in 1862, and even compare it with other geographical areas.

\footnotetext{
${ }^{22}$ Annual handbooks of institutions.

${ }^{23}$ Grew, Raymond; Harrigan, Patrick; Whitney, James. "The Availability of Schooling in NineteenthCentury France.” Journal of Interdisciplinary History, 14, no. 1, 1983, p. 50.
} 


\section{Appendices}

Appendix 1

[1877]

Appendix 2
1877
The yearly evidence of the pupil Bálta Miklós, for the $1876-1877$ school year.

The list of the pupils from the first grade of the 18761877 school year.

\section{Appendix 1}

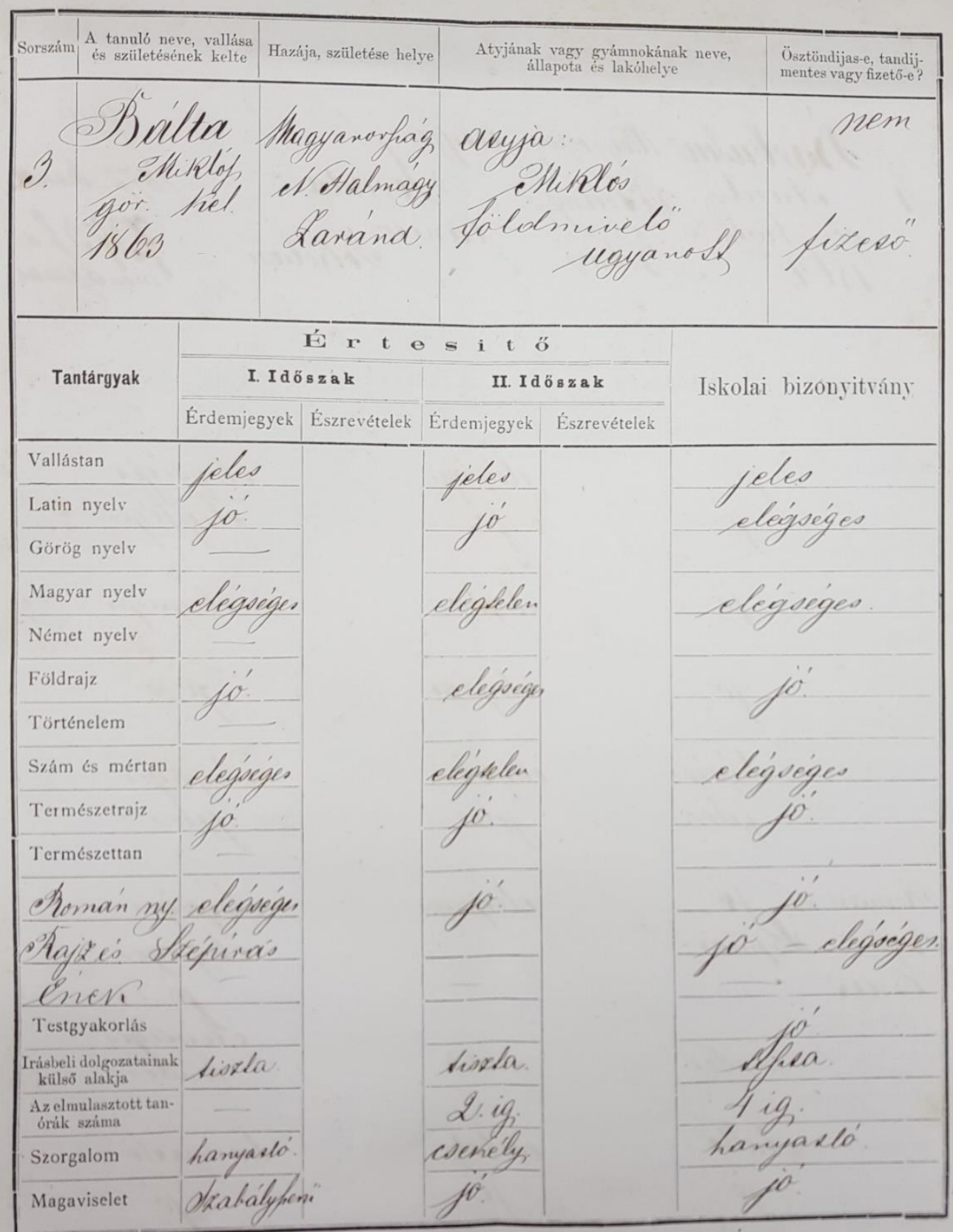

Bihor County Service of the National Archives, „Samuil Vulcan” High School in Beiuș. Transcripts and other registers: inventory no. 1020, dossier no. 27, file no. 3. 


\section{Appendix 2}

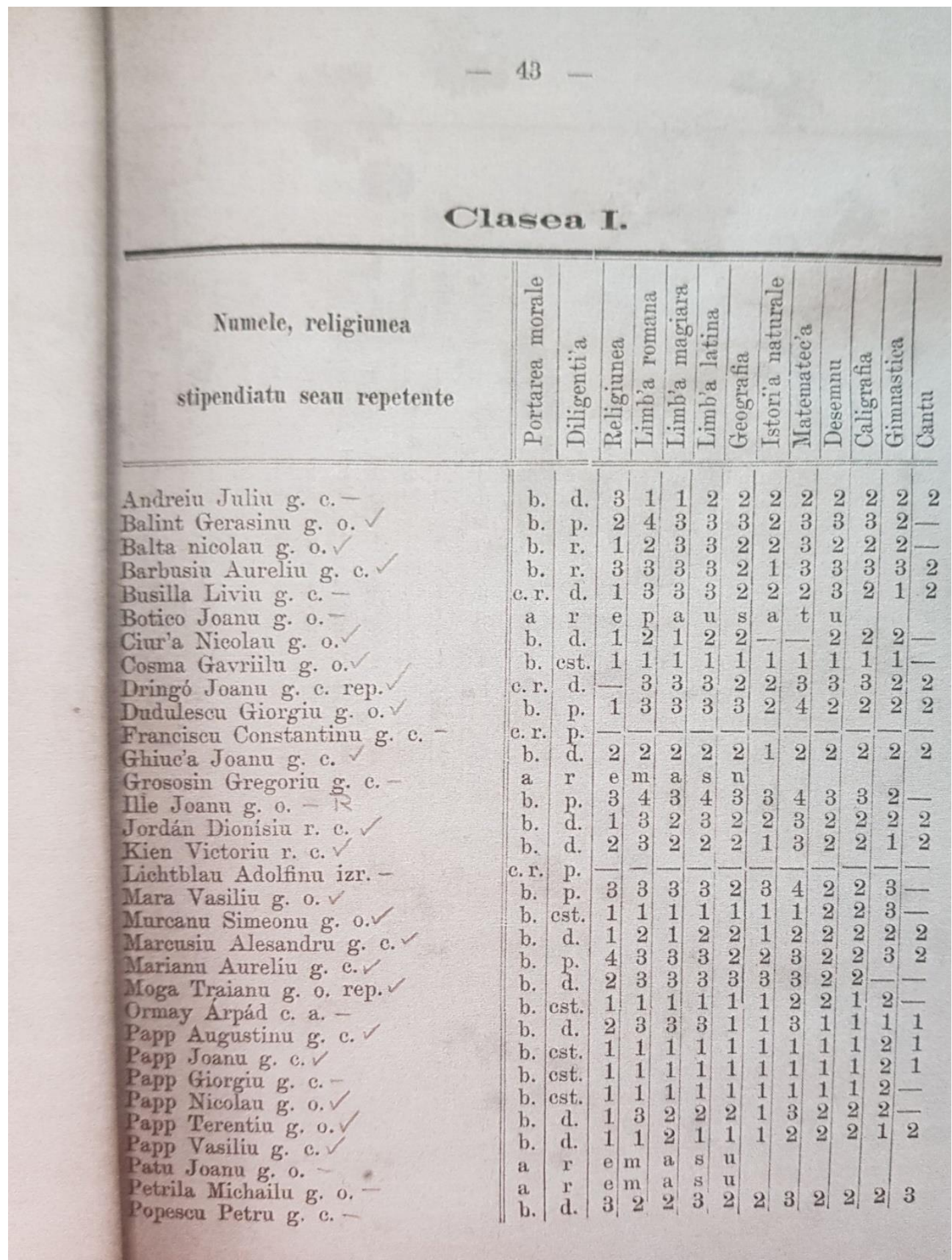

Mihuțiu, Petru (ed.). Reportu despre Gimnasiulu sup. gr. cat. de Beiusiu pentru anulu scol 1876-1877 (Report Regarding the Greek Catholic High School in Beiuș in the 1876/1877 School Year), Tipariulu lui Ludovicu Hollósy, 1877, p. 43. 